\title{
Classical and contemporary contrive of Varti Kalpana
}

\author{
Review article
}

\section{Manish Vyas $^{1^{*}}$ BJ Patgiri' ${ }^{2}$ PK Prajapati ${ }^{3}$}

1. Senior Research Fellow, 2. Reader, 3. Prof. \& Head,

Department of Rasashastra \& Bhaishajya Kalpana,

IPGT \& RA, GAU, Jamnagar (Gujarat) - 361008

\begin{abstract}
Varti Kalpana was in vogue since prehistoric period. Contemporary suppositories are a slight modification of this ancient formulation. Ancient and modern literatures have advocated similar shapes and nearly same routes for administration of Vartis (except Vrana Varti). This formulation is required for the treatment of vital parts and is associated with various important therapeutic activities. A suppository is a medicated solid dosage form intended for use in the rectum, vagina, and to a lesser extent, the urethra. Medicinal plants are huge repertory of innumerable bioactive molecules. They can be traced for their therapeutic potentials and converted into various dosage forms for convenience of treatment. Therefore, recent advances can be utilized for moulding Varti into suppository and enhancing the horizons of therapeutic dosage forms.
\end{abstract}

Key words: Varti, Suppository, Kalpana

\section{Introduction:}

Panchavidha Kashaya Kalpana i.e. five methods of pharmaceutical preparation constitutes the fundamental process of Ayurvedic pharmaceutics, which is well explained in Charaka Samhita(1). Varti Kalpana is one among them, which can be included in Kalka Kalpana. Charaka enjoys the top priority as the treatment aspect is concerned and for the purpose of eradication of diseases. Varti Kalpana plays its own important role. Charaka has mentioned Varti Kalpana at several places in Chikitsa

*Corresponding author:

\section{Dr. Manish Vyas}

Senior Research Fellow

Dept. of RS \& BK,

IPGT \& RA, GAU,

Jamnagar (Gujarat) - 361008

Mob. - 9375776635

E - mail: vymanish@gmail.com
Sthana(2). Further special quotations regarding Varti are available in Siddhi Sthana too(3). Sushruta has also described Varti Kalpana, while explaining the sixty Upkramas (methods of medication) of Vrana(4) and has indicated its use for the treatment of diseases(5). Ashtanga Samgraha and Ashtanga Hridaya both are solely based on Charaka and Sushruta Samhita, hence Varti Kalpana has been mentioned here as well.

The topic of Varti Kalpana has been dealt with almost all the Ayurvedic treatises viz. Vangasena $\left(12^{\text {th }}\right.$ AD), Vrndmadhava (12 ${ }^{\text {th }}$ AD), Gada Nigraha $\left(12^{\text {th }}\right.$ AD), Sharangdhara (14 ${ }^{\text {th }}$ AD), Yogarantakara $\left(16^{\text {th }} \mathrm{AD}\right)$, Bhavaprakasha $\left(16^{\text {th }} \mathrm{AD}\right)$.

Varti Kalpana finds a wide explanation in modern Ayurvedic texts like Bhaishajya Ratnawali (20 ${ }^{\text {th }}$ AD), Rasa Tarangini $\left(20^{\text {th }} \mathrm{AD}\right)$ etc. with a view to treat various ailments. 


\section{Definition (6):}

"Vartiriva Svarupatvata Vartih Namna Prakirtitah",

Medicines are powdered, triturated and given the Varti shape i.e. like the wick of lamp and that is why it is called as Varti Kalpana.

\section{Importance:}

It is used locally as Sthanika Chikitsa. As far as the Ayurvedic mode of treatment is concerned Sthanika Chikitsa is not a negligible one. It has its own importance as same as Sarvadhika Chikitsa. It acts rapidly and in better way to remove the imbalanced state of Doshas and Malas.

Varti Kalpana is required for the treatment of vital parts and is associated with various important therapeutic activities. For example, head is one of the three vital organs and has been called Uttamanga. Varti Kalpana is used to treat various diseases of supraclavicular parts of the body. Likewise Netra Varti(7), Nasa Varti(8)and Dhurma Varti(9)have been advocated to treat the imbalance of Doshas located in upper part of the body.

Varti is used for removal of Sneha after Basti in cases of complication(10). To combat various infections and diseases occurring in Yoni, an enormous list of Varti Kalpana has been indicated by our ancient Acharyas. Some of these may be listed as Rajah Pravartaka Varti, Yoni Sankochaka Varti, Svetapradarntaka Varti(11)etc.

Vrana can occur in any part of the body and usually it is very painful. Acharya Sushruta, while describing sixty Upkramas for the treatment of the treatment of Vrana has indicated Varti Kalpana(12) at no. 28. If used properly, the Varti removes the imbalance of Doshas in the Vrana, by Lekhana and Ropana properties.

In this way, classics have mentioned different types of Vartis to treat diseased condition in different parts of the body.

Types: In Ayurvedic literature different types of Varti have been explained from various angles.

1. Depending upon the size

2. Depending upon its indication at particular site.

3. Depending upon its composition.

4. Depending upon its actions.

\section{Dose and method of its use:}

The dose of Varti and method of its use vary according to its type which are as following:

Netra Varti improves eye sight and is used to cure eye disease like trachoma, Anjanamika, Avranasukra etc. here, the Netra Varti is made wet by dipping in goats or woman's milk or water and is rubbed on the stone to get a paste which is applied locally in the eyes.

Nasa Varti used in the diseases like headache, worms in the supraclavicular region, Tikshna and minute powder of especially indicated drugs, wrapped in cloth, is made to enter into nostrils.

DhumraVarti made of different drugs are put into Dhumranetra and smoke is inhaled to relieve disorders like coryza, headache,disease of supravascular parts, dental diseases and diseases of mouth cavity, respiratory disorders, neck rigidity, hiccup and diseases pertaining to Vata and Kapha Doshas.

Phala Varti used in excretory pathways like rectum, vagina and urinary tracts is called PhalaVarti, which is prepared from different drugs as per requirements.

1. Guda Varti (Rectal suppositories): Guda Varti is used in cases of constipation, retention of enema, disorders of GIT causing obstruction to the flow of Vata and vitiating the Dosha and excretes Mala accumulated in the rectum. The diameter of Varti is made equal to the size of the thumb. When used, the Varti is first soaked in 
Ghrita and then is made to enter in the rectum slowly. Excretion of foecal matter result within 3-4 min. after the use of Guda Varti(13).

2. Yoni Varti (Vaginal suppositories): The Varti is used in the vaginal tract for the treatment of vaginal disorders, like cervicitis, cervical erosions, leucorrhoea, miscarriage and abortion etc. The diameter of this Varti should be equal to that of index finger (14).

3. Sisna Varti (Urethral bougies): The Varti is used in the urethral tract of males to subside the diseases like dysuria, anuria, urinary calculus, pain in the urinary tract and usnavata etc. The length if Varti ranges from 4-12 fingers and diameter should be kept thin.

Vrana Varti, in pyogenic ulcers or wounds after surgery, when pyogenic infections develop proper healing can't occur until the pus is evacuated from the local site. Infection further causes inflammatory reactions. Here, Vrana Varti successfully removes pus and impure blood, leading to proper healing of wounds or ulcers. The drugs are powdered minutely to prepare thin Varti (Vastra Varti) which used to treat Nadivrana, Fistula in ano(15) etc.

Varti Kalpana is used externally; it is of two types, i.e. Saumya and Tikshna. Saumya Varti is indicated for the purpose of Snehana, Poshana and Ropana. Contrary to this Tikshna Varti is used for Virechana and Lekhana Karma. Particular type of activity of a Varti depends up on its ingredients. The drugs used for the Saumya Karma, posses qualities like Mandaguna and Sita Virya, whereas ingredients of Tikshna Varti are Ushna in Virya and Tikshna Guna (16).

\section{Modern review:}

Varti can be equated to modern day suppositories. These are far more popular in Europe as compared to Indian markets. A suppository is a medicated solid dosage form intended for use in the rectum, vagina, and to a lesser extent, the urethra. Rectal and urethral suppositories usually employ vehicles that melt or soften at body temperature, whereas vaginal suppositories, sometimes called pessaries, are also made as compressed tablets that disintegrate in the body fluids.

They can be classified into three main types depending upon their bases: (1) cocoa butter (2) fat and wax combinations with cocoa butter and (3) glycerinated gelatin bases.

Rectal suppositories for adults weigh about $2 \mathrm{~g}$ and are usually tapered to resemble a torpedo shape. Children's suppositories weigh about $1 \mathrm{~g}$ and have a corresponding reduction in size. Vaginal suppositories weigh about $3-5 \mathrm{~g}$ and are usually moulded in the globular or oviform shape, or compressed on a tablet press into modified conical shapes. Urethral suppositories, sometimes called bougies, are pencil shaped and pointed at one extremity. Urethral suppositories intended for males weigh about $4 \mathrm{~g}$ each and are $100-150 \mathrm{~mm}$ long; for females, they are 2 g each and usually $50-75 \mathrm{~mm}$ in length.

Drugs may be administered in suppository form for either local or systemic effects. Such action depends on the nature of the drug, its concentration and the rate of absorption. Emollients, astringents, antibacterial agents, hormones, steroids and local anaesthetics are dispensed in suppository form for treating local conditions of vagina, rectum and urethra.

Recently use of prostaglandin containing vaginal suppositories for interruption of early pregnancy has also been reported. Rectal suppositories are primarily intended for the treatment of constipation and haemorrhoids. Suppositories are also administered for systemic action. A wide variety of drugs are employed, e.g. analgesics, antispasmodics, sedatives, tranquilizers and antibacterial agents. Rectal suppositories are also utilized for systemic 
actions in conditions where oral medication would not be retained or absorbed properly, such as during severe nausea and vomiting or in paralytic ileus(17).

\section{Advantages of suppositories over other dosage forms:}

A number of drugs cannot be administered orally, because either the drugs are affected by the digestive juices or their therapeutic activity is modified by the liver after absorption. Liver modifies many drugs chemically and thereby often reduces their systemic effectiveness. On the other hand, a major portion of same drugs can be absorbed from the anorectal area and still retain therapeutic values. The lower haemorrhoidal veins surrounding the colon and rectum enter into the inferior vena cava and thus bypass the liver. More than half of rectally administered drugs were reported absorbed directly into the general circulation(18). The lymphatic circulation helps also in absorbing a rectally administered drug and in diverting the absorbed drug from the liver (19).

Suppository yields effective blood levels, although, to maintain the therapeutic effectiveness of a drug in a suppository requires wise choice of both the drug salt and the suppository base.

\section{Bases for suppositories:}

More than 40 bases are currently available for preparing various types of suppositories. However an ideal base should melt at rectal temperature of $36{ }^{\circ} \mathrm{C}$, non toxic, non irritating, compatible with a large number of drugs, have wetting and emulsifying properties, stable on storage, easily manufactured by moulding etc. Fatty bases should have acid value below 0.2 , saponification ranges from $200-245$, iodine value less than 7 , small interval between melting and solidification points. Theobroma oil (cocoa butter), hydrophilic bases like glycerinated gelatin, various polyethylene glycols, water dispersible bases etc. are a few widely accepted bases.
General considerations while preparing suppositories:

Availability and cost are issues apart from homogenous distribution of intended drug in the base and release at the desired rate in the aqueous body fluid. If the drug favours water, a fatty base with low water number may be preferred. On the other hand if the drug is highly fat soluble, a water type base, perhaps with the surfactant to enhance the solubility, may be the preferred choice.

To enhance the homogeneity of drug in the desired base, either a suitable solvent is used or the drug is finely communited before incorporation. A drug that is soluble in a minimal quantity of water, or in another liquid miscible with the base, can be dissolved and the solution added to the molten base. If the drug is to be directly incorporated in the base, it should be finely ground so that it can pass through 100 no. mesh.

\section{Testing of suppositories:}

Apart from routine analytical tests for concentration of drug and its homogeneity, melting range test, liquefaction or softening time tests of rectal suppositories, breaking (fragility or brittleness) test, dissolution testing, shelf life studies (at $4{ }^{\circ} \mathrm{C}$ and $25 \pm 3{ }^{\circ} \mathrm{C}$ ) can also be carried out.

\section{Comprehension of ancient and modern concepts:}

Varti Kalpana was in vogue since prehistoric period. Contemporary suppositories are a slight modification of this ancient formulation. During ancient times, the drugs from which the Varti was to be composed were powdered. The necessary items like jaggery and oil etc. were purified and heating procedures were applied in such a way that these items became capable of making soft Varti.

Ancient and modern literatures have advocated similar shapes and nearly same routes for administration of Vartis (except VranaVarti). During ancient times, 
they were dispensed at the request of patient, so there was no need of any bases and least stability concerns. Powders of medicaments were levigated in suitable media or water and the wet mass was converted into desired shape and inserted at required site for therapeutic benefits. They were aimed for attaining quicker relief from conditions of Udavarta, Mutrkriccha, Baddha Koshta etc.

However, recent vigilant entrepreneurs have affixed shelf life of Varti for 2 years (one time use) by the Gazette notification of $6^{\text {th }}$ amendment of D \& C Rules, 1945, Rule 161 B.

\section{Further scope:}

Medicinal plants are huge repertory of innumerous bioactive molecules. They can be traced for their therapeutic potentials and converted into various dosage forms for convenience of treatment. Phala Vartis can be effectively used in cases of constipation, other anorectal complaints. Similarly, Panchavalkala and Sphatika Vartis can be admixed with suitable bases for efficient use in vaginal disorders like leucorrhoea, menorrhagia, metrorrhagia, various rodent and non-healing ulcers etc. Dhumra Vartis can be made into apt forms for felicitating ailing of respiratory disorders. Therefore, recent advances can be utilized for moulding Varti into suppository and enhancing the horizons of therapeutic dosage forms.

\section{References:}

1. Agnivesha, Charaka Samhita, Ayurveda-Dipika commentary by Chakrapanidutta, Chaukhambha Surbharati Prakashan, Varanasi, 2008, Sutra Sthana 4/6

2. Agnivesha, Charaka Samhita, Ayurveda-Dipika commentary by Chakrapanidutta, Chaukhambha Surbharati Prakashan, Varanasi, 2008, Chikita Sthana 5/30
3. Agnivesha, Charaka Samhita, Ayurveda-Dipika commentary by Chakrapanidutta, Chaukhambha Surbharati Prakashan, Varanasi, 2008, Chikitsa Sthana 10/47-48

4. Agnivesha, Charaka Samhita, Ayurveda-Dipika commentary by Chakrapanidutta, Chaukhambha Surbharati Prakashan, Varanasi, 2008, Chikitsa Sthana 26/12-13

5. Agnivesha, Charaka Samhita, Ayurveda-Dipika commentary by Chakrapanidutta, Chaukhambha Surbharati Prakashan, Varanasi, 2008, Siddhi Sthana 9/58-61

6. Sushruta, Sushruta Samhita, Nibandha Sangraha commentary by Dahlana, Chaukhambha Surbharati Prakashana, Varanasi, 2003, Chikitsa Sthana $1 / 51$

7. Sushruta, Sushruta Samhita, Nibandha Sangraha commentary by Dahlana, Chaukhambha Surbharati Prakashana, Varanasi, 2003, Uttara Tantra $18 / 8$

8. Shabdakalpadruma, Raja Radhakant Dev, NagaPublishers, Delhi, 2003, IV Edition, Pg. no. 290

9. Agnivesha, Charaka Samhita, Ayurveda-Dipika commentary by Chakrapanidutta, Chaukhambha Surbharati Prakashan, Varanasi, 2008, Chikitsa Sthana 26/253/255

10. Agnivesha, Charaka Samhita, Ayurveda-Dipika commentary by Chakrapanidutta, Chaukhambha Surbharati Prakashan, Varanasi, 2008, Chikitsa Sthana 26/135

11. Agnivesha, Charaka Samhita, Ayurveda-Dipika commentary by Chakrapanidutta, Chaukhambha Surbharati Prakashan, Varanasi, 2008, Chikitsa Sthana 26/182

12. Agnivesha, Charaka Samhita, Ayurveda-Dipika commentary by Chakrapanidutta, Chaukhambha Surbharati Prakashan, Varanasi, 2008, Siddhi Sthana 9/58-61 
13. Agnivesha, Charaka Samhita, Ayurveda-Dipika commentary by Chakrapanidutta, Chaukhambha Surbharati Prakashan, Varanasi, 2008, Chikitsa Sthana 30/117-120

14. Sushruta, Sushruta Samhita, Nibandha Sangraha commentary by Dahlana, Chaukhambha Surbharati Prakashana, Varanasi, 2003, Chikitsa Sthana $1 / 51$

15. Agnivesha, Charaka Samhita, Ayurveda-Dipika commentary by Chakrapanidutta, Chaukhambha Surbharati Prakashan, Varanasi, 2008, Chikitsa Sthana 26/12-13

16. Agnivesha, Charaka Samhita, Ayurveda-Dipika commentary by Chakrapanidutta, Chaukhambha Surbharati Prakashan, Varanasi, 2008, Chikitsa Sthana 30/73
17. Sushruta, Sushruta Samhita, Nibandha Sangraha commentary by Dahlana, Chaukhambha Surbharati Prakashana, Varanasi, 2003, Chikitsa Sthana $1 / 51$

18. Purohit Chtana et al, Use of YoniVarti in Sveta Pradara, PG dissertation, Dept. of RS\&BK, IPGT \& RA, GAU, Jamnagar, Conceptual study, 1993, pg. 6

19. Lachman and Lieberman, The Theory and Practice of Industrial Pharmacy, CBS Publishers, 2009, Chapter 19, pg. 564-564

20. Bucher K, Helv. Physiol. Et Pharmacol. Acta, 6:821, 1948

21. Fabre MR, Regnier M, Ann. Pharm. Franc., 9:318, 1951 